\title{
Experiences of 5th Grade Students Participating in Active Gaming-Assisted Physical Education Lessons*
}

\author{
Hidayet Suha Yüksel ${ }^{1}$, Fehmi Tuncel ${ }^{1}$ \\ ${ }^{1}$ Faculty of Sport Science, Ankara University, Ankara, Turkey \\ Correspondence: Hidayet Suha Yüksel, Faculty of Sport Science, Ankara University, Ankara, Turkey.
}

Received: November 21, 2017

Accepted: December 21, 2017

Online Published: December 23, 2017

doi:10.11114/jets.v5i13.2882

URL: https://doi.org/10.11114/jets.v5i13.2882

\begin{abstract}
The aim of present study is to explore the experiences of $5^{\text {th }}$ grade students, who participated in physical education courses structured based on the active gaming program. The qualitative case study model was employed in this study. Twelve $5^{\text {th }}$ grade students attending the physical education lessons were involved in present study. The physical education lessons were taught by using "SMART Trainer" system having 3 wall units for 12 weeks. The data were collected using semi-structured focus group discussions, observation notes, rubric, and video records. The content analysis method was used in analyzing the data. The findings were gathered under two categories, two main themes, and four sub-themes. In first category, the previous experiences of students regarding the physical education lessons are to play same games, to watch movies or to take other lessons when they were in the classroom, and to play traditional games or to be left free when they were outside. The fun, the skill-difficulty level, the decrease in awareness of time, the visual-auditory stimulants and the teacher support, which are reflected to the physical education lessons under the motivation theme, are among the important experiences playing role in motivation of students. In physical competence and confidence dimension, the fundamental movement skills assessments made by practitioners as their main function indicate that the majority of students are at adequate levels, whereas it was determined that the self-confidence from the physical aspect developed in parallel with the development of fundamental movement abilities that teachers perceive from their students.
\end{abstract}

Keywords: physical education, active gaming, secondary school, experience, physical literacy

\section{Introduction}

In order to raise individuals that are healthy from every aspect, the adoption of physically active lifestyle by the children has been one of the main objectives of physical education lessons and physical activity programs. National Association for Sport and Physical Education [NASPE] (2009) emphasized that guiding the children in adopting lifelong healthy and active lifestyle is one of the most important objectives of physical education syllabus. At this point, some of the previous studies reported that the physical education courses could not achieve this objective and the children at secondary-school ages are not active enough (Fairclough and Stratton, 2005; McKenzie et al., 2000; Simons-Morton et al., 1994). Another important point regarding this subject is that, even if it is thought that the children generally have fun in physical education lessons (Dyson, 1995), the physical education lesson and physical activity environments are not as it seems especially for the children that have insufficient physical abilities and those have weight problems (Suomi, Collier, \& Brown, 2003). Preparing the physical activity environments that are one of the domains, in which the individual differences frequently come to the forefront, by considering the individual differences of children in the way enabling them to participate in physical activity will be useful in children's decision about participating in physical activity in future (Solomon \& Lee, 2008). The ages, at which the children participate in organized physical activity for the first time, are between $7^{\text {th }}$ and $12^{\text {th }}$ years, and the experiences in this period are very important for the participation of children's participation in sport during the rest of their lives (Kirk, 2005). At this point, offering comprehensive and interesting options that fit to developmental needs of children and increase their social interaction in both of physical education lessons and extracurricular activities would contribute to both of the improvement of children's physical abilities and their participation and attendance to physical activities. The main motivation ensuring the participation of

"This research has been supported by Ankara University Scientific Research Projects Coordination Unit. Project Number: 14A0672002, 2016 
children at that age in physical activity is to have fun and to enjoy, and they focus on playing game rather than training (Kirk, 2005). Since it enables participating in various activities and it contributes to the physical development, the game has always been an important component of child education (Chen, 2013). Together with the technological advancements in recent years, the game entered in our lives via computers, game consoles, and smartphones and they especially became an integral part of children's daily lives. According to the data of Turkish Statistics Institute [TUIK] (2013), 6-15 year-old children's rate of computer use was found \% 60, 5. Besides offering games decreasing the physical activity and increasing the sedentary behaviors, the technology can provide the children with an opportunity to spend more time in exercises and physical activities (Hansen \& Sanders, 2011). Mears and Hansen (2009) named this new type of technology-assisted physical activity, which requires movement, as active gaming. The active games might offer children opportunities of participating in joyful and interesting activities and spending time with friends, as well as improving their physical skills and abilities (Martin et al., 2015). Active games integrate the game and exercise in order to eliminate the harmful effects of sedentary life, and it offers new options to students and teachers in diversifying the activities in physical education (Best, 2013). This approach acts as a bridge between technology-oriented games and physical activity (Witherspoon and Manning, 2012). These technology-oriented activities require the participants to move their body in order to control the game's functions (Foley and Maddison, 2010; Thin, Hansen, and McEachen 2011; Mellecker \& McManus, 2008). This approach establishes a fun and enjoyment culture drawing the interest of children for participating in exercises and physical activity (Hansen and Sanders, 2011). In recent years, adding the active gaming in physical education syllabuses is considered as a very important project in order to draw the attention of children to physical activity and improving their experience in many countries, especially in USA, Canada, and Australia (Chen, 2013). At this point, from the perspective that the technology is an integral part of our lives, the use of technology-assisted active games in preparing the interesting and inclusive activities offering diversity in physical education lessons is very important, as well as carrying out researches on this subject. The objective of present study is to explore the experiences of $5^{\text {th }}$ grade students participating in physical education program involving active games.

\subsection{Active Gaming}

Hansen (2010) divided the active gaming in 3 categories as exercise games, interactive fitness activities, and active learning games. The SMART (Sensory Motor Activity Reaction Training) system, which was used in this study, is the technology-assisted system that is within the interactive fitness activity category and requires player to use his/her body in order to play the game. This system is based on shooting at the target from certain distances within adjustable times or gaining points by directly touching at the system. In parallel with the achievements to be selected, the learning environment and difficulty level can be adjusted, as well as the other materials and activities.

\subsection{Theoretical Framework}

As presented in Figure 1, the main framework in this study consists of "Motivation and Physical Competence-Confidence" concepts that are within the basic cycle of physical literacy concept of Whitehead (2010). The motivation status was examined using concepts coming to the forefront in practice according to the Flow Theory of Csikszentmihalyi (1990). Physical competence and confidence, on the other hand, were examined using fundamental movement skills assessment form and perceived physical competence concept.

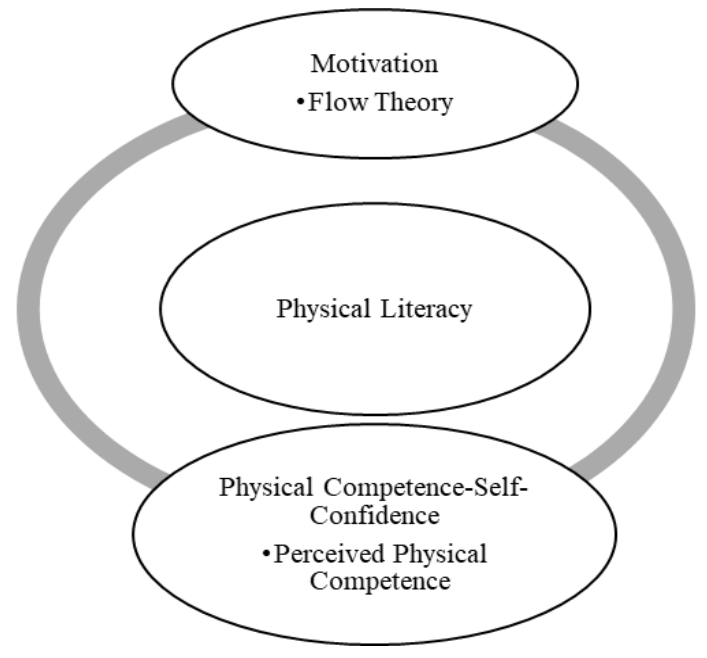

Figure 1. Theoretical Framework 


\subsubsection{Physical Literacy}

The physical literacy can be defined as the motivation, confidence, physical competence, knowledge, and understanding in order to maintain the physical activities throughout the life (Whitehead, 2010). Monism philosophy constituted the basic foundation of physical literacy by advocating that the human is a whole of mind and body. From the perspective of this approach paying importance to physical differences of individuals, the physical literacy focuses on involving the physical activity in the lives of individuals. The final objective of all the programs is to have children to have a life-long habit out of sports. Given the secondary school physical education lesson syllabus in our country, it can be seen that the statement "regularly participates in physical activities and sports in order to be healthy and improve his/her health" indicates that it is aimed to raise individuals regularly participating in sportive activities (Ministry of National Education [MEB], 2013). Physical literacy has been a part of discussion about how the sports, recreation, healthy, and physical education should be in order to deal with the increasing obesity problem arising as a result of immobility (Higgs, 2010). Since it shows that the value of physical activity is much more than the performance, the philosophy and concepts of physical literacy are very useful.

\subsubsection{Flow Theory}

Csikszentmihalyi defined the concept of flow as the condition that the individual feels in his/her action, in which he/she completely participated (Hsu \& Lu, 2004). The flow experience is a phenomenon that refers to individuals having fun and enjoying in an activity (Chang et al., 2017). The active gaming includes various characteristics such as fun, rules, objectives, consequences and feedback, winning, losing, contesting, problem-solving, and interaction (Prensky, 2007). Since it includes characteristics such as net objective, feedback, difficulty-skill balance, combination of action and awareness, sense of control, decrease in awareness of time, loss of self-awareness, and awarding the experience, the flow experiences provide an environment, which can reflect the condition provided by technology-assisted games do (Hoffman \& Novak, 2009). In his study, Csikszentmihalyi (1990) reported that the combination of these characteristics creates a deep appreciation/pleasure, and he concluded that the results achieved throughout the world are similar to each other. One of the environments that are appropriate for flow experience is the environments, in which the games are played, and this theory was used by the researchers in order to understand the experiences of participants in studies carried out in those environments (Cowley, Charles, Black \& Hickey, 2008).

\subsubsection{Perceived Physical Competence}

The perceived physical competence or the perception of physical self is a subcomponent of self-conception, and it includes the person's perception of himself/herself in psychomotor components (strength, endurance, and physical appearance) (Lyu \& Gill, 2011). The children's physical competence perceptions are considered to play important role in their activity selections, and defining the type of competence perception acts as the foundation for understanding the motivated behaviors of children (Bois et al., 2002). In some of previous studies, it was shown that there is a relationship between the perceived physical competence and the participation in physical activities (Carroll, \& Loumidis, 2001; Koca \& Aşç1, 2004; Paxton, Estabrooks, \& Dzewaltowski, 2004).

\section{Method}

\subsection{Context and Research Process}

This study was carried out with $5^{\text {th }}$ grade students studying at Gölbaşı T.E.K Secondary School in educational year 2015-2016. The school, in which the study was carried out, is located at the lodging campus of TEK and at which the children coming from different economic levels and cultural contexts around study together with the children of TEK employees. The school has a sports hall, and the "SMART Trainer" system, which was used during the research period and shown in Figure 1, was set in this hall. This system, which enables the participants to perform interactive exercises and to develop fundamental movement skills, consists of 3 wall units and served to 3 different groups at the same time. Together with the systems, the foam rollers, the balls having different sizes, dimensions, and weights, the balance ball, conies, exercise stairs, hoops, and slaloms were used in order to develop fundamental movement skills and to ensure the activity diversity. During the research process, the learning contents and schedules in harmony with fundamental movement skills in accordance with the $5^{\text {th }}$ grade syllabus were prepared and the physical education lessons were taught by using technology-assisted active game program for 12 weeks. During fundamental movement skill education process, 5-8 physical education programs and physical activity cards [PAC] were utilized. SMART system was used as the instrument, which is finally achieved and from which the points are obtained, in order to make activities more joyful within the scope of learning environment. In this process, the role of researcher was to assist and guide the implementations. Besides the researcher, also two candidate physical education teachers, who have 12-week active game program experience as extracurricular activity, participated in the study. The learning levels of skills were assessed and, according to the results obtained, it was decided if the next phase would be initiated (Criteria: 3-5: Competent, 0-2: Needs to be improved). 


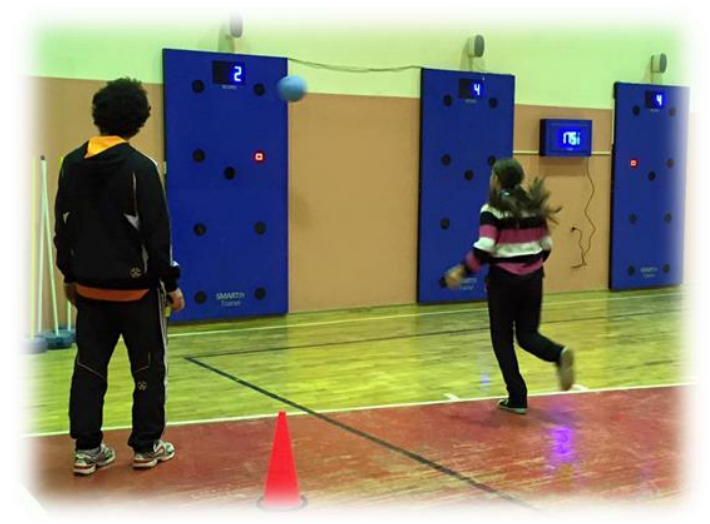

Figure 2. SMART Trainer System in Sports Hall of T.E.K Secondary School

\subsection{Study Model}

In order to investigate the previous experiences of $5^{\text {th }}$ grade students in physical education lessons and their actual experiences in current program, the qualitative case study approach was employed in present study. According to Yin (1984), the case study is a research method, which examines an actual phenomenon within its real environment, in which the borders between the phenomenon and the content covering it and in which there are multiple evidences or data resources (cited by Yıldırım and Şimşek, 2013). The factors determining the structure of phenomenon are determined by focusing on a single case. The phenomenology focuses on the cases, of which we are aware but which we have no deep and detailed understanding about (Yıldırım and Şimşek, 2013). The phenomenology is a study approach consisting of various interventions in order to reveal the subject experienced by the participants (Baden and Major, 2013). In this study, the perspective of phenomenology was used in order to reveal the experiences while studying on an actual content within the real life (Creswell, 2016).

\subsection{Stance of Researcher}

Following his 6-year of experience as a physical education teacher, the researcher has been working at university as research assistant for 5 years. Since his years of teaching, he has constantly sought for the answers of questions such as how to make the lessons more interesting for students and how to increase the active participation. From this aspect, after assigning as research assistant at the university, he focused on the implementations regarding the technology-assisted physical education lessons and extracurricular activities. Prior to this study, he gained experience about the system and applications by practicing with SMART system 3 days per week for 3 months. Besides that, by involving two candidate physical education teachers into the process, he enabled them to recognize the system and gain experience. These candidate teachers played role as practitioners in this study.

\subsection{Participants}

12 students chosen among 30 students studying at T.E.K. Secondary School in educational year 2015-2016 were involved in this study. While selecting the sample, the criterion sampling was preferred. The students highly interested in physical education lesson, as well as those not interested in, were chosen based on their responses to the questions asked in surveys, which were conducted before the implementation, regarding the criteria such as the interest in physical education lesson, extracurricular activity, and physical activity. The reason for selecting specific number of student from the group is to collect data more intensely. 12 students participating in this study are specified in results section by using nicknames.

\subsection{Data Collection Instruments}

The data were collected by using semi-structured focus group discussions, personal interviews, and observation form.

\subsubsection{Interviews}

The semi-structured focus group discussions and personal interviews were used as primary data collection instrument in this study. During these interviews, not only the questions that were prepared by the researcher before the study but also the additional questions were asked in order to understand the interpretations and responses of the participants (Baden, 2013). First of the interviews was conducted 3 weeks after the implementation as initiated, whereas the second one was conducted after the implementation was completed. More attention was given to prior physical education lesson experiences in first interviews and the initial opinions about the program, whereas only the questions about active gaming program were asked in second interviews. While preparing the interview questions, firstly the questions about the prior physical education lesson experiences were prepared, and then the results obtained from studies on similar 
systems and the basic concepts of Csikszentmihalyi's Flow Theory were taken into consideration. The reason for conducting the interviews at different intervals was to obtain more detailed opinion of children about the active games and to understand in which direction the opinions and interests changed as the activities and materials used throughout the program diversified.

\subsubsection{Observation}

The observation is the open-ended and firsthand data collection process by observing the places and persons within the study area (Cresswell, 2012, p: 213). 12 participant students selected from the group consisted of $5^{\text {th }}$ grade students were observed once a week for 10 weeks and the field notes were taken. The observations were used in order to determine if the data collected via interviews and various assessment instruments in parallel with the theoretical framework show parallelism. As an additional instrument, the interviews were recorded by using a digital video-camera. Together with the field notes, the videos were used in order to validate the accuracy of obtained information, to review the overlooked or forgotten information, and to share with the expert faculty members. During the observation, firstly the general environment, in which the program was executed, and then the implementation environment, which helped us understanding the active game experiences of children in physical education lessons, were observed by placing the children at the center. Physical environment, participants, activities, and interactions were taken into consideration during the observation period.

\subsection{Data Analysis}

Content analysis method was used in analyzing the data (Yıldırım and Şimşek, 2013). Within the scope of this analysis method, the data obtained from the research were separately examined by the researcher and the codes were determined. Then these codes were classified under two categories and four themes. Creating the codes and categories constitutes the foundation of qualitative data analysis (Creswell, 2016, p: 184).

\subsubsection{Coding}

After reading the interview and observation texts line-by-line, the codes that were considered important by the researcher were highlighted. The coding process contains collecting the data into small information categories, searching for evidence for incoming code, and the labeling process. In order to achieve more reliable results from coding, the second and third coders were requested, and the classification into the themes was executed through the common codes.

\subsubsection{Thematic Coding}

After finishing the coding, the related codes were gathered together and the appropriate themes were obtained. The thematic coding is to categorize (theme) the predetermined codes by determining the common characteristics. Following the detailed coding and thematic coding, the data were translated into an interpretable format.

\subsection{Validity-Reliability}

Although there are different perspectives regarding the reliability and validity in qualitative studies, the perspective of Lincoln and Guba (1985) was taken into consideration in this study, and the concept of persuasiveness was preferred. The persuasiveness is the most important standard indicating the quality of qualitative research process (Baden, 2013). In order to ensure the persuasiveness of the study, the long-term interaction, data diversification, and detailed description methods were utilized. The researcher spent time with study group approximately for 12 weeks, and the date were diversified with observation form and vide records, in addition to the interviews. The details were related to each other by using intense description, and the strongest citations were used. In order to ensure the reliability, the researcher clearly specified his position in this study, and the characteristics of study group and study area, the theoretical framework utilized in this study, and data collection and analysis process were explained in details.

\section{Results}

The results obtained were interpreted under two categories, two themes, and four subthemes. The children's experiences in physical education lessons in elementary school years were focused under the category of "previous physical education lesson experiences", whereas the experiences gained during the implementation were focused under the category of "active gaming-assisted physical education lesson experiences". In this category, the results were interpreted under the themes of motivation and physical competence - self-confidence concepts that are within the basic cycle of Whitehead's (2010) physical literacy concept.

\subsection{Previous Physical Education Lesson Experiences}

Given the previous physical education lesson experiences of student, it can be seen that the experiences such as playing various games, watching movies, or studying different lessons by staying in the classroom come to the forefront. For instance; 
Ridvan: So, if the weather was bad, we were staying in the classroom and playing a game called "bom" because the teacher believed that we would get sick. But, however, he wasn't teaching the lesson but opening a movie on the smartboard.

Burcu: Our teacher was not taking us out of the classroom at all, and I was not happy with that. We were playing the same games always, and I was not enjoying physical education lesson in elementary school.

Ahmet: Our teacher was sick, thus he couldn't go outside. Instead of that, he was teaching us different lessons such as math.

The in-class activities of our students were the games such as "bom" sounding food. On the other hand, when they left the classroom, they have played traditional game such as "mendil kapmaca (catching the handkerchief)" and "yağ satarım bal satarım (duck duck gose)", in addition to the free activities.

Nurcan: Sometimes we were going outside and playing game such as catching the handkerchief and duck-duck-goose.

Erhan: We were doing funny activities. We were playing games such as playing tag, tombik, and catching the handkerchief. Besides that, around $23^{\text {rd }}$ April (a national special day of Turkey), we have participated in a gunnysack race.

From the statements above, as well as Ali's statement "I don't remember if we wanted but we were generally playing in the classroom, thus we were not taught about those skills" and Selma's statement "He hasn't taught that to us. We have never heard about such points before you came our school", we can understand that our students were not taught fundamental movement skills in elementary school in parallel with the syllabus of Game and Physical Activity lesson.

Besides that, in first semester of $5^{\text {th }}$ grade in secondary school, it can be seen that the students have negative experiences before the active gaming program such as irregularity of lessons, teachers leaving the class, inability of participation of all the students, etc..

Selma: This year, for instance, our teacher was taking the attendance, and then he was leaving. He was entering his room and closing the door, so we couldn't find our teacher. Since the upper grades were also having the same lesson, we were fighting and they were humiliating us. They were taking us out of the hall since there was no teacher ...

Nurcan: All of the students in class were playing dodgeball game, but they were not allowing some of students into the game. They were shouting us when they were tagged. Some of the students were excluded, whereas some others were sitting around or playing the game.

Berna: There was another lesson in class, and we were having contest with them, games such as volleyball and tombik. I was happy with the lesson, but it was a little bit irregular. We were playing games by ourselves, and the teacher was not saying anything.

\subsection{Active Gaming-Assisted Physical Education Lesson Experiences}

From the statements of students and the field implementations, it can be seen that the negativities were at the forefront in previous physical education lesson experiences, and that the lessons were not conducted in parallel with syllabus. Then the reflections of technology-assisted lessons were evaluated within the frame of motivation and physical competence / self-confidence concepts of physical literacy's basic cycle. The physical competence was interpreted by the practitioners by using the assessment forms within the scope of students' perceived physical competence and the education process.

\subsubsection{Motivation}

\subsubsection{Fun, Enjoyment, Constant Interest}

The main factor ensuring the motivation is to be pleased with the subject and to have fun. The main concepts regarding the internal motivation are the enjoyment, fun, and satisfaction (Deci \& Ryan, 2000). From the statements of students, we can understand that these experiences seem to be important in ensuring the motivation reflected on the physical education lessons conducted using SMART Trainer.

Ali: ... we play better games with technological devices... Then this technology system runs and we play different games. We touch those places, we throw balls, I really like it.

Recep: ...I had pain in my foot, but I came to touch at that wall.

Rudvan: I didn't want this lesson to end, I even wanted it to never end. I want to stay for additional lesson, but it is not possible. 
Burcu: I sometimes come here tired, but I don't want to quit the game.

Besides that, according to the opinion of students, the lessons would not be that fun without the technology support.

Eren: ...technological device increased the fun.

Berna: ... with technology support, we were seeing things in color a or $b$ and we were having fun when pressing them.

Burcu: without the technological devices, I become distracted and less interested.

At this point, the program features making students have fun and interest in are the features such as games, content, touching at SMART Trainer, interaction, flashing lights, and feedback.

Ece: We get a point when touching at the technological device and this makes us very happy.

Ahmet: You brought us the technological devices. We play games in different branches. I liked having different games and activities.

Ali: I thought about doing anything to get the light. Reaching at the light and achieving the target build up an interest.

Erhan: sometimes $A, B, C$, and D letters flash in the system. I really liked them...

\subsubsection{Focusing and Decreased Awareness of Time}

One of the 8 prominent characteristics specified by Csikszentmihalyi for the flow status is the decreased awareness of time (Chen, 2007). From the statements of students, it is understood that this feature required for the flow is experienced in physical education lessons conducted by using SMART Trainer system.

Sinem: When we win or lose or when our friends comfort us, I think what if the time is not up and we could play forever. Sometimes, we even think that why it is for 40 minutes rather than 60 minutes. I think time passes too fast.

Nurcan: 1 hour passes like a moment. But, in other lessons, there is an atmosphere like the ringing bell saves us.

At this point, it can be understood from the statements of students that the features of technology-assisted physical education lessons offering entertainment and constant interest have an important potential in terms of losing the awareness of time and living the flow situation. Merve's statement "I cannot understand how fast the time passed and I think how fast the lesson ended" and Pinar's statement “... it passes too fast, because we cannot understand the time passing while we are playing game” corroborate this conclusion.

One of the important concepts in Csikszentmihalyi's flow theory is the focused concentration. The technology support employed in physical education lessons ensures the focus at a single point and this helps both in making students experience the flow experience and in decreasing the distracting student behaviors in classroom.

Şura: These games enabled me to better concentrate and the exercises improved my self-confidence.

Ece: Technology made us to concentrate on the lesson. For example, they wanted to go somewhere else but, now, every student wants to attend and participate in the lesson

\subsubsection{Activity's Challenge Level and Skill Balance}

One of the most important conditions providing the flow is the balance between challenge level and individual's skill. If the difficulty level of activity is much higher than the skill of subject or if it is much lower, then the interest decreases and the subject quits the game (Csikszentmihalyi, 1990). Although the students stated that they sometimes had difficulties but they generally were successful, this statement give clues regarding that the challenge level was slightly higher than their skill level. Moreover, one of the factors ensuring the internal motivation is the success (Deci \& Ryan, 2000). At this point, the fact that the students generally think they are successful ensures their motivation for attending and sustaining the participation in physical activity.

Recep: I became furious about overcoming all the obstacles in order to touch at that wall... otherwise, we would never exert ourselves for this purpose.

Yağlz: I wasn't able to accurately throw the ball in ball-throwing game, and I wasn't successful in rolling it. The skills were more difficult than I expected. Initially I thought that I should let it go, but then, I had my heart in and tried to achieve it.

Elif: I experience both of failure and success. My performance was better than my expectations. In throwing ball to walls, I firstly couldn't, but then I managed it. 
Nurcan: ... I experienced the success and failure at the same time, but I believe that I was generally successful because I believe in myself. I retry if I fail, but never give up.

\subsubsection{Teacher Support and Setting}

The $5^{\text {th }}$ grade, in which the study was carried out, consisted of the students that were in period of transition from elementary school to secondary school and being defined as naughtiest $5^{\text {th }}$ grade students by school's physical education teacher (informal teacher interview). Besides that, as it can be seen in the statements of students regarding the previous physical education lesson experiences, they were away from an achievement-oriented physical education lesson on a regular basis before the beginning of implementation, and they were a group adopting the looseness. As a reflection of this, the behaviors such as irregularity, tussles, humiliations towards each other, and etc. were frequently observed in the classroom. Together with the implementation process, in order to minimize these problems, the draw method was adopted for conducting the activities with a different group every week. In order to increase the educational time within the classroom, it was attempted to develop certain rules and routines. Even though the technology support has certain facilitator features, it is not possible to achieve education without the effective teacher behaviors and preparing a qualified learning environment. Especially specific to this group, establishing the order within the classroom, providing anyone with equal chance of participation, and momentary feedbacks of teachers enabled more efficient course according to the opinion of students.

Mine: These physical education lessons are more informative and educative, and there is that wall. Moreover, both we are in discipline and there are different games ... it is a very different lesson, so it's ok.

Selma: I am happier, I think that this setting is better. I liked it more since the discipline is at higher level. They also do what we have to do, and there is no discrimination.

Erhan: Now, teacher helps me when I failed. You can understand anybody and help them regardless that they are good or bad. There was an irregularity before the teachers came. Not, there is not irregularity and we have more fun.

\subsubsection{Physical Competence and Self-Confidence}

One of the most important components of physical literacy cycle is the physical competence and self-confidence. Development of fundamental movement skills related with physical competence enables children to implement the shills, which they learnt, in sport or recreation environments in future (Bailey, 2006). According to Whitehead (2010), the children that couldn't have rich and comprehensive movement experience at the school ages cannot make the accurate decisions in adulthood. As a result of fundamental movement skill assessment made by 3 practitioners and requiring displacement and object control, the rates of ones considered compatible for the next level are presented in Table 1 .

Table 1. Fundamental movement skills assessment form results

\begin{tabular}{|c|c|c|c|c|c|c|}
\hline \multicolumn{7}{|c|}{ Locomotor Skills } \\
\hline Skills & $\begin{array}{l}\text { Number of students } \\
\text { participating in the } \\
\text { lesson }\end{array}$ & $\begin{array}{l}\text { Number of } \\
\text { competent } \\
\text { ones }\end{array}$ & $\begin{array}{l}\text { Number of ones } \\
\text { needing } \\
\text { improvement }\end{array}$ & $\begin{array}{l}\text { Number of students } \\
\text { participating in the } \\
\text { study }\end{array}$ & $\begin{array}{c}\text { Number of } \\
\text { competent } \\
\text { ones }\end{array}$ & $\begin{array}{c}\text { Number of ones } \\
\text { needing } \\
\text { improvement }\end{array}$ \\
\hline Running & 27 & 22 & 5 & 12 & 11 & 1 \\
\hline Jumping & 27 & 20 & 7 & 12 & 11 & 1 \\
\hline Skip & 27 & 21 & 6 & 12 & 11 & 1 \\
\hline Gallop & 27 & 22 & 5 & 12 & 11 & 1 \\
\hline Slide step & 27 & 22 & 5 & 12 & 12 & 0 \\
\hline \multicolumn{7}{|c|}{ Object Control Skills } \\
\hline Skills & $\begin{array}{l}\text { Number of students } \\
\text { participating in the } \\
\text { lesson }\end{array}$ & $\begin{array}{c}\text { Number of } \\
\text { competent } \\
\text { ones }\end{array}$ & $\begin{array}{c}\text { Number of ones } \\
\text { needing } \\
\text { improvement }\end{array}$ & $\begin{array}{l}\text { Number of students } \\
\text { participating in the } \\
\text { study }\end{array}$ & $\begin{array}{c}\text { Number of } \\
\text { competent } \\
\text { ones }\end{array}$ & $\begin{array}{c}\text { Number of ones } \\
\text { needing } \\
\text { improvement }\end{array}$ \\
\hline Throwing & 30 & 27 & 3 & 12 & 12 & 0 \\
\hline Catching & 30 & 23 & 7 & 12 & 10 & 2 \\
\hline Kicking & 30 & 23 & 7 & 12 & 10 & 2 \\
\hline Dribbling & 30 & 24 & 6 & 12 & 11 & 1 \\
\hline
\end{tabular}

- For each of the skills, the ones meeting minimum 3 out of 5-6 different criteria assessed by 3 practitioners were considered competent, whereas others were considered to need improvement.

The results obtained from the assessment indicate that many of the students achieved a condition, which can be considered as appropriate, regarding fundamental movement skills. Besides that, the students' physical competence perception is also important in ensuring the participation in physical activity (Bois et al., 2005). When they consider 
themselves as competent, the self-confidence of students will develop and thus their participation in activities will continue. The self-assessments of students indicate that their skills developed. Mehmet's statement "gallop, skip, and running developed" and Şura's similar statement "I learned galloping, throwing something, and jumping-leaping", as well as Selma's statement "I believe that I learned more. I heard gallop for the first time. Catcing, skip, and racket games drew out attention, and we could do those we never could" indicate that the students believe that they developed and got better.

Besides that, the students saw that they could do it when they found practical opportunities. Their successes encouraged them and helped in terms of self-confidence.

Selin: For example, I saw one of my characteristics, which I have never known. I can control objects and, when I realize it, I feel happier. For examine, when others say that the thing I made is good, I feel happier and work much more on that. I realized it in this period, and I didn't know it before. When we started playing the games, I asked to myself if I had no ability in that game.

Berna: I realized differences in myself. When playing with my friends in our neighborhood, I kick the ball more steadily while playing ball. These further increased my self-confidence.

Yă̆lz: Together with the activities, my self-confidence increase. Both I am not under pressure and my self-confidence increased since I saw that I could do.

Kerem: I helped me increasing my self-confidence. For instance, I am not good at accuracy. I couldn't kick the ball in dodgeball with goal line. I can see the improvement now.

On the other hand, even though the students considered themselves in fundamental movement skills insufficient during general assessments, they saw improvement in their skills during 12 weeks program and this shows us how important these active gaming-assisted programs are.

Ridvan: I became more accurate in throwing the balls, and slightly better in running. I have more flexibility in jumping now.

During the opposite cases, in which the students were considered sufficient by the teacher but the students believe that could not performed the movements, and the statements of those students that they lost their self-confidence indicated how important the perceived physical competence was.

Elif: I had self-confidence but it decreased in the course of time. My self-confidence decreased as I couldn't perform certain skills.

\section{Discussion}

In this study, the experiences of $5^{\text {th }}$ grade students participating in physical education lessons based on active gaming were explored. It was concluded that the previous experiences of students include negative situations such as being left away from the physical education lessons, playing traditional games, or studying another lesson in the classroom. The experiences play important role in shaping the attitudes and behaviors. The experiences, which make people happy when remembered, strengthen the attendance to sports environments, whereas the experiences inducing bad feelings keep individuals away from these environments (Strean, 2009). The children at early ages (7-12 year-old) should be provided with activities structured in the way improving their technical and tactical understandings in the games (Kirk, 2005). According to the results obtained from present study, it can be seen that the previous physical education lessons that do not meet these requirements further increase the importance of physical education lesson and sports experiences in secondary school period. One of the most important factors determining the attendance of children in physical education and sports is the physical competence and skill development. The children at 8-12 age group start to recognize their abilities and accordingly they make their decision about attending in or avoiding form the activity (Lee et al., 1995). For this reason, if the fundamental movement skills are not taught sufficiently in elementary school years, in which the students are at above mentioned ages, then the skill differences of students might increase even more and it might cause them to stay away from activities.

The motivation concept plays an important role in active gaming experiences. The experiences at early ages constitute an important step for lifelong attendance to the sports, and the main motivation at these ages is the pleasure and joy (Kirk, 2005). The prominent results obtained from the study indicate that the students had fun and enjoyed within the scope of program, and that their interest continues. At this point, the concept of motivation that is within the basic cycle of physical literacy concept, principles of which were specified by Whitehead (2010), is important since it indicates that the motivation is an integral part of participation in sports. The results obtained from studies on this subject corroborate that the technology-assisted systems increase the motivation (Pasco et al., 2017; Hansen and Sanders, 2010; Sun, 2013). Csikszentmihalyi (1990) defined the flow status as the most important status of internal motivation at the moment, in 
which the person completely focuses on doing. Deci and Ryan (2000), on the other hand, defined the factors ensuring internal motivation as fun, satisfaction, and pleasure. According to the results obtained, experiencing the situations such as fun, pleasure, and interest in physical education lessons indicated that the motivation has a reflection on the technology-assisted implementations. As one of the factors ensuring the motivation, the fun has an important place in technology-assisted applications. In study of Hansen and Sanders $(2010)$ on $5^{\text {th }}$ grade students, one of the themes coming up is the fun. Besides that, the students stated that their sense of time altered during the lessons and time passed very fast. An altered sense of time in a person indicates the intense motivation, and this is taken into consideration in interactive digital games and systems (Hold \& Mitterer, 2000). The finding indicates that a suitable environment for experiencing the flow situation was prepared in physical education lessons based on active gaming. Another important factor for the flow experience is to establish the balance between difficulty level of activity and skill level of individual. From the statements of students, it can be understood that the activities are difficult but still at the levels, which they can handle with. In a study on determining the characteristics of physical education experiences that are meaningful for the students, Kretchmar (2006) reported that the difficulty level of activities, in which the students are involved, should be neither too difficult nor too easy.

The decrease in temporal motivation indicates the intense motivation and interactive systems generally take this into consideration (Hold \& Mitterer, 2000). Since the students think that the time passed too fast, it indicates that the decreased awareness of time is experienced. At this point, in the studies on videogames and active games, it was reported that these games enabled the decrease in awareness of time, which is one of the important characteristics of flow experience (Hsu and Lu, 2004; Chang et al., 2017; Cowley et al., 2008).

Another important phase of physical literacy cycle is the physical competence and confidence. At this point the results of present study were taken into consideration in two ways, and, also with perceived physical competence and confidence were discussed in the interviews with students in addition to the assessments of practitioners. The fundamental movement skill assessments made by practitioners in this study indicated that the students were considered generally competent. Moreover, the students also stated that they developed in terms of various motor skills from the aspect of physical competence. Lewis (2014) reported in his study on examining the school-based physical education experiences of students that students' participation by taking pleasure feels competent and it occurred in cases, in which they have the control and are supported by the others. In addition to the physical competence, also the perceived physical competence is very important in attendance to the sports. Ulrich (1987), in his study on 250 students, reported that there is a significant relationship between fundamental movement skills and attendance to the sport, and that the physical competence perceptions of the children affected the motor skills they exhibited. Another result of the study is that the children emphasized a development in their self-confidence in parallel with the development in physical competence. Self-competence, perceived competence, and perceived ability related with sport-related confidence are defined as the capacity, which a person perceives in order to succeed at certain levels (Feltz, 1988). Gaining and developing fundamental movement skills in elementary school ages are very important for the physical activities of adolescents (Barnett et al., 2009). The fundamental movement skills gained at these ages would directly affect the self-confidence and self-respect related with the physical literacy, and would be useful in overcoming the obstacles in the path to lifelong participation in physical activities. Physical education lessons and physical activities that are fun, developing positive self-perception, ensuring internal motivation, and improving perceived competence are positively related with the attendance to physical activity in future (Rossi et al., 2015).

\section{Conclusion and Recommendations}

The results obtained from this study were examined under the categories of previous physical education lesson experiences of students and their experiences in physical education lesson based on the active gaming. It was determined that the previous physical education lesson experiences of students were different from the elementary school game and physical activity syllabus, and that they have experiences such as being left for playing or studying different studies in classroom or playing traditional games or having free time in schoolyard.

The experiences of students during the physical education lesson based on active gaming were examined in terms of motivation, physical competence, and confidence concepts of physical literacy's basic cycle. In the process of interpreting the motivation dimension, the flow theory of Csikszentmihalyi (1990) and the internal motivation concept of Deci and Ryan (2000) were utilized. Within this context, the facts that the students had fun during the implementation process, that they took pleasure, that they had constant interest in this subject, that they focused, that there was a balance between the activity's difficulty level and students' skill level, that their awareness of time decreased, and that the practitioners conducting the physical education lessons constantly offer assistance and motivation came to the forefront as experiences facilitating the motivation. 
From the aspect of ensuring the physical capability, the physical education lessons were structured based on the idea that the students should perform the fundamental movement skills expected from a student, who recently graduated from elementary school, and the assessment was made by the practitioners by using the fundamental movement skill assessment form. As a result of these assessments, it was concluded that most of the students are considered to be competent by the practitioners. The physical competence was also examined from the aspect of perceived physical competence, which is a concept related with self-confidence, and it was observed that the students perceived an improvement in themselves regarding the motor skills related with movements requiring displacement and object control. In parallel with this improvement perception, they stated an improvement in self-confidence and self-respect dimensions and it indicates that the physical education lessons structured based on active gaming might contribute to the process of physical literacy.

From the aspects of results obtained here, it can be concluded that the findings such as the integration of technology into the lives of children as an integral part and the consequent increase in inactiveness necessitate the games interacting with motion as a part of physical education lessons or extracurricular physical activities. From this perspective, it is important to carry out further studies on the contributions of physical education lessons or extracurricular activities integrated with technology. In this process, the studies focusing on the role of physical education teacher might be useful for evaluating the subject from another perspective. Since such systems are not used in Turkey yet, different systems might be used within various project contexts and the studies might be carried out on this content. From the aspect of struggling with the obesity that is one of the most important problems arising due to immobility, such systems might be used in examining the health-related physical competence parameters of students such as energy consumption in physical education lessons or extracurricular physical activities, aerobic endurance, anaerobic endurance, muscle power, and flexibility. Besides that, the experimental studies should be carried out on the effects of technology-assisted programs on various motor skills. The candidate teachers were involved in this study as practitioners. It is very important that the physical education teachers should be trained in the in-service programs on the use of technology-assisted systems, and that involving them into such implementation processes is very important for understanding their opinions about the subject.

\section{References}

Baden, M., \& Major, C. H. (2013). Qualitative research: The essential guide to theory and practice. Routledge.

Bailey, R. (2006). Physical Education and Sport in Schools: A review of benefits and outcomes. Journal of School Health, 76(8), 397-401. https://doi.org/10.1111/j.1746-1561.2006.00132.x

Barnett, L. M., Van Beurden, E., Morgan, P. J., Brooks, L. O., \& Beard, J. R. (2009). Childhood motor skill proficiency as a predictor of adolescent physical activity. Journal of adolescent health, 44(3), 252-259. https://doi.org/10.1016/j.jadohealth.2008.07.004

Bois, J. E., Sarrazin, P. G., Brustad, R. J., Trouilloud, D. O., \& Cury, F. (2002). Mothers' expectancies and young adolescents' perceived physical competence: A yearlong study. The Journal of Early Adolescence, 22(4), 384-406. https://doi.org/10.1177/027243102237189

Bois, J. E., Sarrazin, P. G., Brustad, R. J., Trouilloud, D. O., \& Cury, F. (2005). Elementary school children's perceived competence and physical activity involvement: the influence of parents' role modelling behaviours and perceptions of their child's competence. Psychology of sport and exercise, 6(4), 381-397. https://doi.org/10.1016/j.psychsport.2004.03.003

Carroll, B., \& Loumidis, J. (2001). Childrenís perceived competence and enjoyment in physical education and physical activity outside school. European physical education review, 7(1), 24-43. https://doi.org/10.1177/1356336X010071005

Chang, C. C., Liang, C., Chou, P. N., \& Lin, G. Y. (2017). Is game-based learning better in flow experience and various types of cognitive load than non-game-based learning? Perspective from multimedia and media richness. Computers in Human Behavior, 71, 218-227. https://doi.org/10.1016/j.chb.2017.01.031

Chen A. (2013). Effects of exergaming and the physical education curriculum, Journal of Sport and Health Science, 2(3), 129-130, ISSN 2095-2546

Chen, J. (2007). Flow in games (and everything else). Communications of the ACM, 50(4), 31-34. https://doi.org/10.1145/1232743.1232769

Cowley, B., Charles, D., Black, M., \& Hickey, R. (2008). Toward an understanding of flow in video games. Computers in Entertainment (CIE), 6(2), 20. https://doi.org/10.1145/1371216.1371223

Creswell, J. W. (2012). Educational research: Planning, conducting, and evaluating quantitative (Fourth edition). Pearson 
Creswell, J. W. (2016). Nitel araştırma yöntemleri: Beş yaklaşıma göre nitel araştırma ve araştırma deseni (3.Bask1). Ankara: Siyasal Kitabevi.

Csikszentmihalyi, M. Flow: The Psychology of Optimal Experience. Harper Perennial, London, 1990.

De Rossi, P., Mattews, N., MacLean, M., \& Smith, H. (2015). Building a repertoire: exploring the role of active play in improving physical literacy in children. Revista Universitaria de la Educación Física y el Deporte, (5), 38-45.

Deci, E. L., \& Ryan, R. M. (2000). The" what" and" why" of goal pursuits: Human needs and the self-determination of behavior. Psychological inquiry, 11(4), 227-268. https://doi.org/10.1207/S15327965PLI1104_01

Dyson, B. P. (1995). Students' voices in two alternative elementary physical education programs. Journal of teaching in physical education, 14(4), 394-407. https://doi.org/10.1123/jtpe.14.4.394

Fairclough, S., \& Stratton, G. (2005). 'Physical education makes you fit and healthy'. Physical education's contribution to young people's physical activity levels. Health education research, 20(1), 14-23. https://doi.org/10.1093/her/cyg101

Feltz, D. L. (1988). Self-confidence and sports performance. Exercise and sport sciences reviews, 16(1), 423-458. https://doi.org/10.1249/00003677-198800160-00016

Foley, L., \& Maddison, R. (2010). Use of active video games to increase physical activity in children: a (virtual) reality. Pediatr Exerc Sci, 22(1), 7-20. https://doi.org/10.1123/pes.22.1.7

Hansen, L., \& Sanders, S. (2010). Fifth Grade Students' Experiences Participating in Active Gaming in Physical Education: The Persistence to Game. ICHPER-SD Journal of Research, 5(2), 33-40.

Hansen, L.W., \& Sanders, S.W. (2011). Active gaming: The new paradigm in children's physical activity. DIGITAL CULTURE \& EDUCATION, 3(2), 123-136

Higgs, C. (2010). Physical literacy-Two approaches, one concept. Literacy, 6(2), 127-138.

Hoffman, D. L., \& Novak, T. P. (2009). Flow online: lessons learned and future prospects. Journal of Interactive Marketing, 23(1), 23-34. https://doi.org/10.1016/j.intmar.2008.10.003

Holt, R., \& Mitterer, J. (2000). Examining video game immersion as a flow state. 108th Annual Psychological Association, Washington, DC.

Hsu, C. L., \& Lu, H. P. (2004). Why do people play on-line games? An extended TAM with social influences and flow experience. Information \& management, 41(7), 853-868. https://doi.org/10.1016/j.im.2003.08.014

Kirk, D. (2005). Physical education, youth sport and lifelong participation: the importance of early learning experiences. European Physical Education Review, 11(3), 239-255. https://doi.org/10.1177/1356336X05056649

Koca, C., \& Aşçı, F. H. (2004). Atletik Yeterlik Düzeyi ve Cinsiyetin Beden Eğitimine Yönelik Tutum Üzerine Etkisi. Gazi Beden Eğitimi ve Spor Bilimleri Dergisi, 15.

Lee, A. M., Carter, J. A., \& Xiang, P. (1995). Children's conceptions of ability in physical education. Journal of Teaching in Physical Education, 14(4), 384-393. https://doi.org/10.1123/jtpe.14.4.384

Lewis, K. (2014). Pupils' and teachers' experiences of school-based physical education: a qualitative study. BMJ open, 4(9), e005277. https://doi.org/10.1136/bmjopen-2014-005277

Lyu, M., \& Gill, D. L. (2011). Perceived physical competence, enjoyment and effort in same-sex and coeducational physical education classes. Educational psychology, 31(2), 247-260. https://doi.org/10.1080/01443410.2010.545105

Martin, N. J., Ameluxen-Coleman, E. J., \& Heinrichs, D. M. (2015). Innovative Ways to Use Modern Technology to Enhance, Rather than Hinder, Physical Activity among Youth. Journal of Physical Education, Recreation and Dance, 86(4), 46-53. https://doi.org/10.1080/07303084.2015.1009205

McKenzie, T. L., Marshall, S. J., Sallis, J. F., \& Conway, T. L. (2000). Student activity levels, lesson context, and teacher behavior during middle school physical education. Research quarterly for exercise and sport, 71(3), 249-259. https://doi.org/10.1080/02701367.2000.10608905

Mears, D. \& Hansen, L. (2009). Active gaming: Definitions, and implementation. Strategies Journal, 23(2), 26-29. https://doi.org/10.1080/08924562.2009.10590864

Mellecker, R. R., \& McManus, A. M. (2008). Energy expenditure and cardiovascular responses to seated and active gaming in children. Archives of Pediatrics \& Adolescent Medicine, 162(9), 886-891. https://doi.org/10.1001/archpedi.162.9.886 
National Association for Sport and Physical Education. (2009a). Appropriate use of instructional technology in physical education. Reston, VA: Author

Pasco, D., Roure, C., Kermarrec, G., Pope, Z., \& Gao, Z. (2017). The effects of a bike active video game on players' physical activity and motivation. Journal of Sport and Health Science, 6(1), 25-32. https://doi.org/10.1016/j.jshs.2016.11.007

Paxton, R. J., Estabrooks, P. A., \& Dzewaltowski, D. (2004). Attraction to physical activity mediates the relationship between perceived competence and physical activity in youth. Research quarterly for exercise and sport, 75(1), 107-111. https://doi.org/10.1080/02701367.2004.10609139

Prensky, M. (2007). Changing paradigms. Educational technology, 47(4), 1-3.

Robinson, L. E. (2011). The relationship between perceived physical competence and fundamental motor skills in preschool children. Child: care, health and development, 37(4), 589-596. https://doi.org/10.1111/j.1365-2214.2010.01187.x

Scott Kretchmar, R. (2006). Ten more reasons for quality physical education. Journal of Physical Education, Recreation \& Dance, 77(9), 6-9. https://doi.org/10.1080/07303084.2006.10597932

Simons-Morton, B. G., Taylor, W. C., Snider, S. A., \& Huang, I. W. (1993). The physical activity of fifth-grade students during physical education classes. American Journal of Public Health, 83(2), 262-264. https://doi.org/10.2105/AJPH.83.2.262

Solmon, M. A., \& Lee, A. M. (2008). Research on social issues in elementary school physical education. The Elementary School Journal, 108(3), 229-239. https://doi.org/10.1086/529105

Strean, W. B. (2009). Remembering instructors: Play, pain and pedagogy. Qualitative research in sport and exercise, 1(3), 210-220. https://doi.org/10.1080/19398440903192290

Sun, H. (2013). Impact of exergames on physical activity and motivation in elementary school students: A follow-up study. Journal of Sport and Health Science, 2(3), 138-145. https://doi.org/10.1016/j.jshs.2013.02.003

Suomi, J., Collier, D., \& Brown, L. (2003). Factors affecting the social experiences of students in elementary physical education classes. Journal of Teaching in Physical Education, 22(2), 186-202. https://doi.org/10.1123/jtpe.22.2.186

Sweetser, P., \& Wyeth, P. (2005). Game Flow: a model for evaluating player enjoyment in games. Computers in Entertainment (CIE), 3(3), 3-3. https://doi.org/10.1145/1077246.1077253

Thin, A., Hansen, L., \& McEachen, D. (2011). Flow experience and mood states while playing body movement-controlled video games. Games and culture, 1555412011402677. https://doi.org/10.1177/1555412011402677

TUIKK. (2013). 06-15 Yaş Grubu Çocuklarda Bilişim Teknolojileri Kullanımı ve Medya. Accessed from http://www.tuik.gov.tr/PreHaberBultenleri.do?id=15866

Ulrich, B. D. (1987). Perceptions of physical competence, motor competence, and participation in organized sport: Their interrelationships in young children. Research Quarterly for Exercise and Sport, 58(1), 57-67. https://doi.org/10.1080/02701367.1987.10605421

Wan, C. S., \& Chiou, W. B. (2006). Psychological motives and online games addiction: A test of flow theory and humanistic needs theory for Taiwanese adolescents. Cyber Psychology \& Behavior,9(3), 317-324. https://doi.org/10.1089/cpb.2006.9.317

Whitehead, M. (Ed.). (2010). Physical literacy: Throughout the life course. Rout ledge.

Witherspoon, L., \& Manning, J. P. (2012). Active Gaming: The Future of Play?. American Journal of Play, 4(4), 464-487.

Yıldırım, A., \& Şimşek, H. (2013). Sosyal bilimlerde nitel araştırma yöntemleri. Ankara: Seçkin Yayıncılık.

\section{Copyrights}

Copyright for this article is retained by the author(s), with first publication rights granted to the journal.

This is an open-access article distributed under the terms and conditions of the Creative Commons Attribution license which permits unrestricted use, distribution, and reproduction in any medium, provided the original work is properly cited. 